\title{
Comparative aspects of the dual role of the human atrioventricular node
}

\author{
FRITS L MEIJLER \\ From the Department of Cardiology, University Hospital Utrecht, The Netherlands
}

SUMMARY As well as transmitting the impulse from the atria to the ventricles the atrioventricular node has two other important functions namely: (a) synchronisation of atrial and ventricular contractions by a var ying delay; and $(b)$ protection of the ventricles from rapid atrial arrhythmias. The relative importance of these two functions appears to differ in large and small mammalian hearts. In small mammals synchronisation of atrial and ventricular contractions is the major function of the atrioventricular node, whereas protection from rapid atrial arrhythmias may be its most important function in large mammals. Atrioventricular conduction time in sinus rhythm is ten times longer in the whale $(500 \mathrm{~ms})$ than in the rat $(50 \mathrm{~ms})$. A whale heart, however, is about 100000 times heavier than a rat heart. During atrial fibrillation the ventricular rate in a dog heart is only three times faster than in a horse, whereas a horse heart may be $\mathbf{4 0}$ times as heavy as that of a dog. Hence there is a considerable discrepancy between the size of the mammalian heart and the functions of its atrioventricular node. Analysis of several anatomical and functional aspects of atrioventricular conduction systems in mammals of all sizes showed that the importance of the delaying role of the atrioventricular conduction system diminishes as the size of the mammal increases, whereas the protective role of the atrioventricular node probably increases. The function of the human atrioventricular node seems to be intermediate between that of the small and large mammals.

In normal hearts electrical impulses travelling from the atria to the ventricles have to traverse the atrioventricular node. "The relation between heart size and the time intervals of the heartbeat with particular reference to the elephant and the whale" was reported by White and his associates almost 70 years ago. ${ }^{1-3}$ They stressed the essential role of the atrioventricular conduction system in determining the $\mathrm{PR}$ interval and QRS duration. ${ }^{4}$ Traditionally the atrioventricular node is regarded as the delay and synchronisation centre between atrial and ventricular contractions. ${ }^{56}$ Precise tuning of atrioventricular delay optimises the contribution of atrial contraction to ventricular filling and subsequent contraction. Such adjustments allow some human beings to run the $100 \mathrm{~m}$ within 10 seconds or to cover the marathon in less than $2 \frac{1}{2}$ hours.

Requests for reprints to Dr Frits L Meijler, Interuniversity Cardiology Institute, PO Box 19258, 3501 DG Utrecht, The Netherlands.

Accepted for publication 19 November 1985
Patients with the Wolff-Parkinson-White syndrome have an accessory pathway directly connecting the atria and the ventricles. This connection lacks the protective delay of the normal atrioventricular node. ${ }^{78}$ The electrophysiological properties of the accessory atrioventricular pathway, for example a short refractory period or a limited capacity for concealed conduction or both, ${ }^{9-13}$ result in a bypass or short circuit of the normal atrioventricular connection.

Because they lack normal atrioventricular nodal delay such patients are more susceptible to ventricular tachycardia or even ventricular fibrillation in the presence of rapid atrial arrhythmias such as atrial fibrillation.

Thus, in addition to its potential to act as an emergency pacemaker, the human atrioventricular node has two equally important functions: $(a)$ a synchronisation of atrial and ventricular contractions by a varying delay; and $(b)$ protection of the ventricles from atrial tachycardias. A comparative analysis of this dual atrioventricular nodal role in various mam- 
malian hearts may help us to a better understanding of atrioventricular conduction in human beings under normal and abnormal conditions.

\section{COMPARATIVE MORPHOLOGY}

All mammalian hearts have essentially the same architecture. A knowledge of the anatomy of the heart of one species usually makes recognition of corresponding anatomical details in other mammalian hearts easy. Nature has used the same blueprint for all mammalian hearts from the mouse to the whale. ${ }^{14}$

In addition there are considerably more similarities than differences between the ultrastructure of cardiac muscle in different mammals, for example the presence of transverse tubules in mammalian myocardial fibres. ${ }^{1516}$ Moreover, cardiac muscle cells tend to be of uniform diameter (approximately 10 to $15 \mu \mathrm{m}) .^{16-18}$ The diameter of mammalian myocardial fibres reflects an optimal relation between cell volume and the oxygen diffusion rate. ${ }^{19}$ Furthermore, there is little difference in metabolic rate per gram tissue between the rabbit and elephant. ${ }^{20}$ Hence, not only do the blueprints of all mammalian hearts show great similarities, but the bricks with which the mammalian hearts are built are of similar size and form.

Despite the great anatomical similarities in the mammalian atrioventricular conduction systems, ${ }^{2122}$ there are geometrical and morphological differences as well. ${ }^{2324}$ For instance, the so called classic, large Purkinje cells of the heart are found mainly in the larger mammals like ungulates, elephants, and whales. In small mammals the special conduction fibres can be identified only by the absence of transverse tubules. ${ }^{1624}$ In human hearts the distribution of Purkinje cells seems to be related to maturity and heart size. In infants and children it is rare to find Purkinje cells in the bundle branches. $^{25}$

\section{HEART WEIGHT IN MAMMALS OF DIFFERENT SIZES}

Heart weight varies nearly as the first power $(0.98)$ of body weight over essentially the whole mammalian range. ${ }^{26}$ The weight of the mammalian heart is about $0.6 \%$ of the body weight. ${ }^{27}$ From comparative anatomical studies 212224 it appears that the size (volume would be a better word) of the atrioventricular mammalian node also increases with the size of the heart, although not in a fully proportional manner. The heart of a 30 ton whale weighs approximately 100000 times as much as the heart of a $300 \mathrm{~g}$ rat and one would expect that the whale's atrioventricular node would also be about 100000 times larger than that of a rat. In terms of length rather than volume or weight the atrioventricular node of the whale will be $40-50$ times greater than that of the rat. These considerable differences in size of the atrioventricular node are not reflected in the functions of the atrioventricular conduction system. $^{28}$

\section{COMPARATIVE FUNCTION}

Atrioventricular conduction time in the rat is about $40-50 \mathrm{~ms}$ while even in the largest whales it is probably not more than $500 \mathrm{~ms}^{.28}{ }^{29}$ Heart rate in a large whale is $6-10$ beats per minute except when the animal is diving, ${ }^{30}$ and in the rat it is $300-360$ beats per minute.

The postulated scaling factor between the whale and the rat for the estimated volume of the atrioventricular node is 100000 , but the ratio of atrioventricular conduction times is only 10 . Thus there is a 10000 fold mismatch between size and function. There is a similar discrepancy between dimensions of the heart and function in QRS duration, which is $150-200 \mathrm{~ms}$ in the elephant or whale and $10-20 \mathrm{~ms}$ in the rat. ${ }^{29}$ In 1927 Clark observed that "The most striking thing is, that the $P-R$ interval varies so little in different animals. The delay at the a.-v. junction therefore varies relatively little in different species of mammals." 28

\section{ATRIAL FIBRILLATION}

Since all mammalian myocardial cells are approximately the same size, the hearts of large mammals must contain very many more cells than small hearts. ${ }^{17}$ As early as 1914 Garrey, ${ }^{31}$ and more recently Moe and his group, ${ }^{32}{ }^{33}$ showed that large hearts are more vulnerable to fibrillation than small hearts. In fact the rat heart rarely if ever fibrillates. ${ }^{34}$ Atrial fibrillation would be expected to occur quite often in large mammals, and this is certainly borne out by findings in horses. ${ }^{35}$

Possibly because the organisation of atrial and ventricular electrical excitation differs ${ }^{36} 37$ atrial fibrillation is much more common than ventricular fibrillation.

The magnitude of differences between ventricular rate and rhythm during atrial fibrillation in dog, man, and horse is remarkably small considering their great differences in heart size. ${ }^{38}$ For instance, the median ventricular rate during atrial fibrillation in the horse is $50-60$ beats per minute compared with $150-180$ beats per minute in the dog. Thus during atrial fibrillation the horse heart beats only three times more slowly although it is at least 40 times larger. Neither the anatomical nor the physiological basis for this relatively small difference in ventricular rate is known. It is unlikely to be due to differences in the nature of atrial fibrillation itself, 
since few morphological and electrophysiological differences have been seen between different types of mammalian atrial cells. ${ }^{1539}$ Possibly the atrioventricular nodes of larger mammals contain fewer cells per given volume of node. ${ }^{22}$

\section{ATRIOVENTRICULAR CONDUCTION VELOCITY} Despite the considerable difference in the size of their hearts there is little difference between the atrioventricular conduction times of, for example, the horse and the whale. ${ }^{29}$ The same is true for the $P R$ interval in relation to age (and thus heart size) in man-this ranges from $100-110 \mathrm{~ms}$ in the neonate to only $150-200 \mathrm{~ms}$ in the adult. ${ }^{40}$ It is also striking that the timing of the atrial contraction relative to the ventricular contraction appears to be fairly constant in larger hearts-for example those of the horse, elephant, and whale. Moreover, I have observed that in the elephant, for instance, there is little change in PR duration with heart rate; this accords with data presented by White et al. ${ }^{2}$

Given that diastole lasts longer in large mammals, the duration of the PR interval may have less influence on efficient ventricular ejection in larger animals. The importance of the role of the atrioventricular node for tuning atrioventricular delay seems to diminish as the size of the heart increases.

Since the size and arrangement of Purkinje fibres within the His bundle are very similar in sheep and whales ${ }^{16}$ such features cannot explain why the PR interval in the whale is only twice as long as that in the sheep. Similar fibre diameter in the $\mathrm{His}$ bundles should result in similar conduction velocities $^{4142}$; however, Pressler ${ }^{43}$ and others ${ }^{445}$ reported a disparity between conduction velocity and fibre diameter. Sommer and Johnson believe that an increase in the diameter of the conduction fibres from approximately $10 \mu \mathrm{m}$ in the small mammal to around $50 \mu \mathrm{m}$ in the hearts of large mammals can explain the faster conduction in large mammals. ${ }^{15}$

Conduction velocity may also increase within the Purkinje fibres as the size of the animal increases. Unfortunately the data that are most relevant to these assertions-that is those from the mouse, elephant, and whale-are not available. The arrangement of the fibres within the bundles and intercellular resistance may also affect conduction velocity.

The conduction velocity in the large branches of the human heart is about $2.5 \mathrm{~m} / \mathrm{s}^{46} \mathrm{In}$ a large whale the His bundles are probably about one metre long. To obtain PR intervals of $500 \mathrm{~ms}$ (or less), at the same atrioventricular nodal delay, conduction velocity within the His bundles of a large whale would have to be 20-40 times faster than in the human

heart. This seems highly unlikely. Assuming a more or less similar conduction velocity in the whale's $\mathrm{His}$ bundles as in those of the human heart, it would take several hundred ms to cover the distance from atrioventricular node to the intramyocardial Purkinje network. If this assumption is true, the atrioventricular node in a whale's heart is unlikely to contribute much to the total PR interval. ${ }^{28}$

\section{Discussion}

The preceding arguments suggest that impulse delay and synchronisation in the atrioventricular node may not be important in very large mammals such as the elephant and whale. In such animals the atrioventricular node can make little or no contribution to atrioventricular conduction delay $\stackrel{\infty}{\circ}$ because propagation through the His bundle(s) itself $\frac{\text { ㅇ }}{2}$ must account for most of the atrioventricular con- $\rightarrow$ duction time. Nevertheless, the atrioventricular node remains important in larger mammals. Large mammals, such as human beings and horses, particularly older ones, often develop atrial fibrillation.3747-49 The major importance of the atrioventricular node in large mammals may well be the protection of the ventricles against fibrillation or tachycardias during atrial fibrillation or other rapid atrial arrhythmias.

The human body is near the median of the logarithmic mammalian weight scale; in terms of atrioventricular node function it also occupies an intermediate position. In the young the atrioventricular node beautifully synchronises atrial and ventricular contractions, so that strenuous exercise may be performed. In old age the function of the atrioventricular node in protecting the individual against arrhythmias becomes crucial to survival. The dual role of the atrioventricular node in the human heart represents a watershed between atrioventricular nodal function in the small and the large mammalian species.

This paper is the result of lengthy discussions with and the constructive criticism of many friends and $N$ colleagues.

Supported by the Wijnand $M$ Pon Foundation, Leusden, The Netherlands.

\section{References}

1 White PD, King RL, Jenks J. The relation of heart size 0 to the time intervals of the heartbeat with particular $\mathbb{D}$

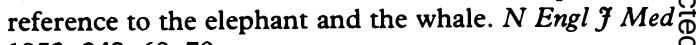
1953; 248: 69-70.

2 White PD, Jenks JL, Benedict FG. The electro- 
cardiogram of the elephant. Am Heart $\mathcal{f} 1938$; 16: 744-50.

3 King RL, Jenks JL, White PD. The electrocardiogram of a Beluga whale. Circulation 1953; 8: 387-97.

4 White PD, Kerr WJ. The heart of the sperm whale with special reference to the AV conduction system. Heart 1917; 6: 207-10.

5 Rushmer RF. Cardiovascular dynamics. 4th ed. Philadelphia: WB Saunders, 1976:87-8.

6 Dagget WM, Bianco JA, Powell WJ, Austen WG. Relative contributions of the atrial systole-ventricular systole interval and of patterns of ventricular activation to ventricular function during electrical pacing of the dog heart. Circ Res 1970; 27: 69-79.

7 Dreifus LS, Haiat R, Watanabe Y, Arrigage J, Reitman $\mathrm{N}$. Ventricular fibrillation. A possible mechanism of sudden death in patients with Wolff-Parkinson-White syndrome. Circulation 1971; 43: 520-7.

8 Boineau JP, Moore EN. Evidence for propagation of activation across and accessory atrio-ventricular connection in types $\mathrm{A}$ and $\mathrm{B}$ pre-excitation. Circulation 1970; 41: 375-97.

9 Wellens HJJ, Durrer D. Wolff-Parkinson-White syndrome and atrial fibrillation. Relation between refractory period of accessory pathway and ventricular rate during atrial fibrillation. Am $\mathcal{f}$ Cardiol 1974; 34: 777-82.

10 Klein GJ, Yee R, Sharma AD. Concealed conduction in accessory atrioventricular pathways: an important determinant of the expression of arrhythmias in patients with Wolff-Parkinson-White syndrome. Circulation 1984; 70: 402-12.

11 Svinarich JT, Yan Tai D, Mickelson J, Keung ECG, Sung RJ. Electrophysiological demonstration of concealed conduction in anomalous atrioventricular bypass tracts. F Am Coll Cardiol 1985; 5: 898-903.

12 Meijler FL. An "account" of digitalis and atrial fibrillation. F Am Coll Cardiol 1985; 5: 60A-8A.

13 Meijler FL, Van der Tweel I, Herbschleb JN, Hauer RNW, Robles de Medina EO. Role of atrial fibrillation and AV conduction in sudden death. $\mathcal{F}$ Am Coll Cardiol 1985; 5: 17B-22B.

14 Meijler FL. Atrioventricular conduction versus heart size from mouse to whale. $\mathcal{F}$ Am Coll Cardiol 1985; 5: 363-5.

15 Sommer JR, Johnson EA. Ultrastructure of cardiac muscle. In: Berne RM, Sperelakis N, Geiger SR, eds. Handbook of physiology. The cardiovascular system I. The heart. Bethesda, Maryland: American Physiological Society, 1979: 113-86.

16 Sommer JR, Johnson EA. Comparative ultrastructure of cardiac cell membrane specializations. Am $\mathcal{f}$ Cardiol 1970; 25: 184-94.

17 McMahon ThA, Tyler Bonner J. On size and life. New York: Scientific American Library, 1983: 5-9.

18 Berril NJ. The determination of size. In: Willier $\mathrm{BH}$, Weiss PA, Hamburger V, eds. Analysis of development. Philadelphia: WB Saunders, 1955: 620-30.

19 Black-Schaffer B, Grinstead CE II, Braunstein JN. Endocardial fibroelastosis of large mammals. Circ Res 1965; 16: 383-90.

20 Schmidt-Nielsen K. Energy metabolism, body size and problems of scaling. Fed Proc 1970; 29: 1524-32.

21 James TN. Anatomy of the sinus node, AV node and os cordis of the beef heart. Anat Rec 1965; 153: 361-72.

22 James TN. Structure and function of the AV junction. fpn Circ F 1983; 47: 1-47.

23 Truex RC, Smythe MQ. Comparative morphology of the cardiac conduction tissue in animals. Ann NY Acad Sci 1965; 127: 19-33.

24 Sommer JR, Dolber PC. Cardiac muscle: ultrastructure of its cells and bundles. In: Paes de Carvalho A, Hoffman BF, Lieberman M, eds. Normal and abnormal conduction in the heart. Mount Kisco, NY: Futura Publishing Company, 1982: 1-27.

25 Davies MJ, Anderson RH, Becker AE. The conduction system of the heart. London: Butterworths, 1983: 9-70.

26 Prothero J. Heart weight as a function of body weight in mammals. Growth 1979; 43: 139-50.

27 Schmidt-Nielsen K. Animal physiology, adaptations and environment. 2nd ed. Cambridge: Cambridge University Press, 1979: 99-112.

28 Clark AJ. Comparative physiology of the heart. Cambridge: Cambridge University Press, 1927: 49-51.

29 Altman PL, Dittmer DS. Biological handbooks: respiration and circulation. Bethesda, Maryland: Federation of American Societies for Experimental Biology, 1971: 278.

30 Slijper EJ. Whales and dolphins. Ann Arbor: The University of Michigan Press, 1978: 51-9.

31 Garrey WE. The nature of fibrillary contraction of the heart. Its relation to tissue mass and form. Am $\mathfrak{f}$ Physiol 1914; 30: 397-414.

32 Moe GK. On the multiple wavelet hypothesis of atrial fibrillation. Arch Int Pharmacodyn 1962; 140: 183-8.

33 Moe GK, Rheinboldt WC, Abildskov JA. A computer model of atrial fibrillation. Am Heart $\mathcal{f}$ 1964; 67: 200-20.

34 Meijler FL, Heethaar RM, Harms FMA, et al. Comparative atrioventricular conduction and its consequences for atrial fibrillation in man. In: Kulbertus HE, Olsson SB, Schlepper M, eds. Atrial fibrillation. Mölndal, Sweden: Astra Cardiovascular, 1982: 285-92.

35 Deem DA, Fregin GF. Atrial fibrillation in horses: a review of 106 clinical cases, with consideration of prevalence, clinical signs, and prognosis. $f \mathrm{Am}$ Vet $\mathrm{Med}$ Assoc 1983; 180: 261-5.

36 Durrer D, Van Dam RTh, Freud GE, Janse MJ, Meijler FL, Arzbaecher RC. Total excitation of the isolated human heart. Circulation 1970; 41: 895-912.

37 Van der Kooi MW, Durrer D, Van Dam RTh, Van der Tweel LH. Electrical activity in sinus node and atrioventricular node. Am Heart $\mathcal{F}$ 1956; 51: 864-700.

38 Meijler FL, Van der Tweel I, Herbschleb JN, Heethaar RM, Borst C. Lessons from comparative studies of atrial fibrillation in dog, human and horse. In: Zipes DP, Jalife J, eds. Cardiac electrophysiology and arrhythmias. Orlando: Grune and Stratton, 1985: 489-93.

39 Hoffman BF, Cranefield PF. Electrophysiology of the heart. New York: McGraw-Hill, 1960: 44-5.

40 Lepeschkin E. Modern electrocardiography. Baltimore: Williams and Wilkins, 1951: 195-204.

41 Jack JJB, Noble D, Tsien RW. Electric current flow in excitable cells. Oxford: Clarendon, 1975: 292-6. 
42 De Mello WC. Passive electrical properties of the atrioventricular node. Pflügers Arch 1977; 371: 135-9.

43 Pressler ML. Cable analysis in quiscent and active sheep Purkinje fibres. I Physiol (Lond) 1984; 352: 739-57.

44 Lieberman M, Koopey JM, Johnson EA, Sawanobori T. Slow conduction in cardiac muscle. A biophysical model. Biophys f 1973; 13: 37-55.

45 Schoenberg M, Dominguez G, Fozzard HA. Effect of diameter and conductance of sheep Purkinje fibres. $\mathcal{F}$ Gen Physiol 1975; 65: 441-58.

46 Durrer D, Janse MJ, Lie KI, Van Capelle FJL. Human cardiac electrophysiology. In: Dickinson CJ, Marks J, eds. Developments in cardiovascular medicine. Lancaster: MTP press, 1978: 53-75.

47 Kannel WB, Abbott RD, Savage DD, McNamara PM. Epidemiologic features of chronic atrial fibrillation: The Framingham Study. $N$ Engl f Med 1982; 302: 1018-22.

48 Meijler FL. Atrial fibrillation: a new look at an old arrhythmia. f Am Coll Cardiol 1983; 2: 391-3.

49 Meijler FL, Kroneman J, Van der Tweel I, Herbschleb JN, Heethaar RM, Borst C. Non-random ventricular rhythms in horses with atrial fibrillation and its significance for patients. $\mathcal{F} \mathrm{Am}$ Coll Cardiol 1984; 4: 316-23.. 